\title{
Ziram'ın Daphnia magna Straus üzerine toksik etkisinin, antioksidan enzim aktivitesi ve antioksidan sistemle ilişkili genlerin ekspresyonu kullanılarak değerlendirilmesi
}

\author{
Evaluation of the toxic effect of Ziram on Daphnia magna straus using antioxidant enzyme \\ activity and expression of antioxidant system related genes
}

Feyza İÇOĞLU AKSAKAL*1,a

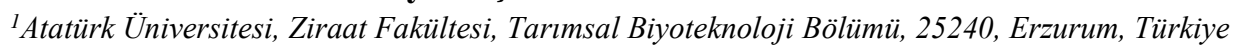

• Geliș tarihi / Received: 21.04.2020 • Düzeltilerek geliş tarihi / Received in revised form: 21.10.2020 • Kabul tarihi / Accepted: 07.11.2020

$\ddot{O} z$

Ziram çok sayıda tarım ürününde haşere kontrolü için evrensel olarak kullanılan geniş spektrumlu bir dimetilditiyokarbamat fungusittir. Bu fungusite tatlı su ekosistemlerinde rastlanılmasına rağmen, yapılan literatür taramalarında ziramın sucul yaşam üzerine toksisitesi hakkında fazla çalışmaya rastlanmamıştır. Bu çalışmada, ziramın bir su omurgasızı olan Daphnia magna üzerine akut toksisitesi değerlendirilmiştir. Bu amaçla, D. magna neonatlarına 48 saat süresince 4 farklı konsantrasyonda ziram uygulanmıştır. Çalışmada, malondialdehit miktarı (MDA), süperoksid dismutaz (SOD), katalaz (CAT), glutatyon S-transferaz (GST) enzim aktiviteleri ve bu enzimler ile ilişkili genlerin ifadelerindeki değişimler ölçülmüştür. Sonuçlar zirama maruziyetin D. magna'da malondialdehit miktarını, antioksidan enzim aktivitelerini ve antioksidan sistemle ilişkili genlerin ifadelerini artırdığını ortaya koymuştur. Sonuç olarak zirama kısa süreli maruz kalmanın D. magna'da oksidatif strese yol açarak akut toksisiteye neden olduğu belirlenmiştir.

Anahtar kelimeler: Akut toksisite, Daphnia magna, Enzim aktivitesi, Gen ekspresyonu, Ziram

\begin{abstract}
Ziram, a broad spectrum fungicide, is a dimethyl-dithiocarbamate universally used for pest control in many agricultural crops. Although ziram is being found in freshwater ecosystems, limited information is found about the toxicity of ziram on aquatic life. Therefore, in the present study, the acute toxicity of ziram on Daphnia magna, a freshwater invertebrate, was evaluated. For this purpose, neonates were exposed to four different concentrations of ziram for 48 hours. Malondialdehyde (MDA) level, superoxide dismutase (SOD), catalase (CAT), glutathione S-transferase (GST) enzyme activities and the changes in the expression of genes related to antioxidant enzymes were measured. The results showed that exposure to ziram significantly increased MDA levels, activities of antioxidant enzymes, and the expression of genes related to antioxidant system in D. magna. In conclusion, it was determined that short term exposure to ziram lead to acute toxicity by causing oxidative stress in D. magna.
\end{abstract}

Keywords: Acute toxicity, Daphnia magna, Enzyme activity, Gene expression, Ziram

*a Feyza İÇOĞLU AKSAKAL, ficoglu@atauni.edu.tr, Tel: +90 44223113 51, orcid.org/0000-0002-0176-6695 


\section{Giriş}

Ziram, dimetil-ditiyokarbamat fungusit ailesine ait geniş spektrumlu bir pestisittir. Bu fungusit ilk olarak 1960'lı yıllarda Amerika Birleşik Devletleri'nde piyasaya sürülmüştür (US EPA, 2004). Günümüzde ise ülkemiz dahil İtalya, Japonya, Çin, Hindistan ve ABD gibi ülkelerde yaygın olarak kullanılmaktadır (Cao vd., 2019). Ziramın 2015 yılında pestisit pazarındaki payı 2 milyon doları geçmiştir (US EPA, 2015). Bu fungusit ilk olarak şeftalide yaprak kıvrılması, domateste antraknoz ve erken yanıklık gibi hastalıkların tedavi edilmesinde kullanılmıştır (US EPA, 2004). Günümüzde ise sert çekirdekli meyveler, yumuşak çekirdekli meyveler, sebzeler ve ticari olarak yetiştirilen süs bitkileri üzerindeki çeşitli mantar hastalıklarını tedavi etmek için yaygın olarak kullanılmaya devam etmektedir (Matei ve Trombetta, 2016). Ziram bitkiler üzerine ortalama haftada bir kez spreyleme yöntemi ile dönüm başına 28,7 $\mathrm{kg}$ olarak uygulanmaktadır (Cao vd., 2019). Ziramın yoğun kullanımı bu fungusitin kalıntılarının karasal ve sucul ortamlarda birikmesine yol açmakta, insanlar dahil hedef olmayan çeşitli organizmalar üzerinde olumsuz etkiler oluşturmaktadır (Lulla vd., 2016). Ziram bakteriler için toksiktir ve topraktaki biyodegradasyonu oldukça yavaştır. Yapılan epidemiyolojik çalışmalar ziram ve diğer ditiyokarbamat fungusitlerin insanlarda nörotoksisiteye yol açtığ 1 ve parkinson hastalığ 1 riskini artırdığını ortaya koymuştur (Lulla vd., 2016; Martin vd., 2016). Ziramın ubikitin protezom sistemini baskilamak yoluyla dopaminerjik hücrelerde hasar oluşturduğu ve böylece parkinson hastalığının gelişimine katkı yaptığı bildirilmiştir (Chou vd., 2008). Shafi vd. (2016) tarafindan ziramın tavuklarda immün sistemi baskıladığ 1 ve toksisiteye neden olduğu rapor edilmiştir. Yine bu fungusitin siçan beyninde bulunan hipokampal astrosit hücrelerinde sitotoksisiteye ve lipid peroksidasyonuna yol açtığı, glutatyon peroksidaz aktivitesini artırdığ $\breve{~ v e ~}$ oksidatif stresi tetiklediği tespit edilmiştir (Matei ve Trombetta, 2016). Aynı çalışmada ziram toksisitesinin hücrelerde reaktif oksijen türevlerinin birikimi ile ilişkili olduğu kaydedilmiştir. Bilindiği gibi canlılar ditiyokarbamat fungusitlere maruz kaldığında hidrojen peroksit, süperoksit radikali ve hidroksil radikali gibi reaktif oksijen türevleri hücrelerde birikmektedir. $\mathrm{Bu}$ reaktif oksijen türevleri hücrelerden hemen uzaklaştırılmazsa hücre zarlarında hasara ve lipid peroksidasyonuna neden olmaktadır. Canlılar reaktif oksijen türevlerinin oluşturduğu hasarı önlemek için süperoksit dismutaz (SOD), katalaz (CAT), glutatyon-Stransferaz (GST) gibi antioksidan enzimler ve glutatyon ve askorbik asit gibi düşük moleküler ağırlıklı antioksidanlardan oluşan bir savunma sistemine sahiptir (Zhang vd., 2016). Thangavel vd. (2005) $0.8 \mu \mathrm{l} / \mathrm{L}$ konsantrasyondaki ziramın bir tatlı su balığı olan Oreochromis mossambicus Peters serumunda prolaktin seviyesini ve kalsiyum, fosfor ve magnezyum miktarını önemli oranda düşürdüğünü tespit etmişlerdir. Yine Cao vd. (2019) zebra balığı larvalarına uygulanan ziramın larvalarda mortalite oranını artırmak, koryondan çıkış oranını ve kalp atış hızını düşürmek yoluyla gelişimsel toksisiteye yol açtığını belirtmişlerdir.

Literatürde balıklar gibi hedef olmayan sucul organizmalar üzerine ziramın toksik etkileri hakkında çeşitli çalışmalar yapılmış olmakla birlikte, bu fungusitin sucul omurgasizlar üzerinde oluşturduğu toksik etkiler hakkında detaylı çalışmalar yapılmamıştır. Oysa su omurgasızlarının önemli bir kısmı besin zincirinin ikinci halkasını oluşturan birincil tüketicilerdir ve ikincil tüketiciler olarak kabul edilen omurgasızlar ve balıkların da içerisinde yer aldığı omurgalı hayvanların besinini oluştururlar (Bang vd., 2015). Daphnia magna Straus kimyasalların sucul ekosistemler üzerine toksisitesini değerlendirmek için sıklıkla kullanılan bir model organizmadır. $\mathrm{Bu}$ türün yaşam süresinin kısa olması, toksik ajanlara yüksek duyarlılığı ve laboratuvar koşullarında kolayca kültüre edilebilmesi onu standart bir test organizması yapmaktadır (Kim vd., 2017). Ayrıca D. magna partenogenetik olarak çoğalabildiğinden dolayı genetik tekdüzelik sağlar ve bundan dolayı moleküler çalışmalar için oldukça uygun bir türdür (İcoğlu Aksakal, 2019).

Barata vd. (2005) D. magna'da lipid peroksidasyonunun yanı sira SOD, CAT ve GST enzim aktivitelerinin pestisitlere maruz kalmaya farklı tepkiler verdiğini rapor etmiştir. Bu nedenle, bu çalışmada, zirama maruz kalmanın D. magna' da lipid peroksidasyonu, bazı antioksidan enzimlerin aktivitesi ve bu enzimleri kodlayan genlerin ifadesi üzerine etkisi araştırılmıştır.

\section{Materyal ve metot}

\subsection{Kimyasallar}

Çalışmada kullanılan ziram (CAS: 137-30-4, Saflık $>\%$ 97) Sigma Aldrich (USA) firmasindan temin edilmiştir. Çalışmada kullanılan konsantrasyonları hazırlamak için ziram DMSO'da (dimetil sülfoksit) (\%0.01) çözündürülmüştür. Deneylerde kullanılan RNA izolasyon kiti Qiagen (Katalog No: 74104), 
cDNA sentez kiti Qiagen (Katalog No: 205311) ve SYBR Green RT-PCR kiti Qiagen (Katalog No: 204243) firmasından satın alınmıştır.

\subsection{Daphnia magna ve Akut toksisite testi}

D. magna OECD 202 test k1lavuzunda belirtilen yöntemlere göre 4 litre su içeren 5 litrelik cam tanklarda 16:8 (1şık:karanlık) periyodunda, $20 \pm 1$ ${ }^{\circ} \mathrm{C}$ sıcaklık koşullarında, $8.2 \pm 0.2 \mathrm{pH}$ 'da muhafaza edilmiştir. 48 saatlik akut toksisite testi için 24 saatten küçük neonatlar kullanılmıştır. Bu amaçla, 20 neonat $400 \mathrm{ml}$ ziram solüsyonu içeren 500 ml'lik cam erlenlerde 48 saat inkübe edilmiştir. Her bir konsantrasyon için 8 deney seti kullanılmıştır ( $8 \times 20=160$ neonat) ve deneyler üç tekrarlı olarak yapılmıştır. Deneylerde kullanılan konsantrasyonlar önceki çalışmalar (Cao vd., 2019; Lulla vd., 2016) ve yapılan ön deneyler sonucu seçilmiştir. Ön deneyler için kontrol, DMSO kontrol (\%0.01), 25, 50, 100, 200, 400, 800, 1600 ve $3200 \mathrm{nM}$ ziram konsantrasyonları kullanılmış ve 48 saatlik $\mathrm{LC}_{50}$ değeri probit analizi kullanılarak hesaplanmıştır. Deneyler esnasında yalnız \%0.01 DMSO uygulanmış DMSO kontrol grubu ve kontrol grubu arasinda istatistiksel olarak anlamlı bir farkl1lık belirlenmemiştir. Bu yüzden, sonuçlar verilirken ziram uygulanmış gruplar yalnız kontrol grubu ile kıyaslanmıştır. Ayrıca 25 ve $50 \mathrm{nM}$ konsantrasyonlarda kontrole göre fazla bir değişim gözlenmediğinden dolayı deneylerde kontrol, 100, 200, 400 ve $800 \mathrm{nM}$ ziram konsantrasyonları kullanılmıştır. Test solüsyonları 24 . saatte değiştirilmiştir. Deney sonunda neonatlar soğuk ortamda tüplere alınmış ve hemen $-80^{\circ} \mathrm{C}$ 'lik derin dondurucuya konulmuştur.

\subsection{MDA miktarl ve antioksidan enzim aktivitelerinin belirlenmesi}

MDA miktarı, Choi ve Oris (2000) tarafindan tarif edilen yöntem kullanılarak saptanmıştır. MDA miktarını belirlemek için $200 \mu \mathrm{l}$ süpernatant $\% 10$ 'luk $1 \mathrm{ml}$ TCA ve $2 \mathrm{ml} \%$ 6'llk TBA ile karıştırılmış, karışım 30 dakika sıcak su banyosunda $\left(100^{\circ} \mathrm{C}\right)$ inkübe edilmiş, numuneler oda sıcaklığında soğumaya bırakılmış ve 12000 g'de 10 dakika santrifüj edilmiştir. Oluşan pembe renk spektrofotometrede (Shimadzu UVmini1240) 532 nm'de okunmuştur. MDA seviyesi $\mathrm{nmol} / \mathrm{mg}$ protein olarak verilmiştir. Toplam protein içeriğini belirlemek için Bradford (1976) tarafından tarif edilen yöntem kullanılmışıtır.

Antioksidan enzim aktiviteleri için numuneler, 1 mM EDTA, $0.25 \mathrm{M}$ sükroz, $0.1 \mathrm{M}$ Tris-HCL (pH 7.4) içeren 4 hacim tamponunda homojenleştirilmiştir. Daha sonra numuneler, 4 ${ }^{\circ} C^{\prime}$ de 15 dakika boyunca 12000 x g'de santrifüjlenmiştir. Süpernatant antioksidan enzim aktivitelerini belirlemek için kullanılmıştır.

SOD aktivitesi, Crapo vd. (1978) tarafindan bildirildiği gibi sitokrom c indirgemesinin inhibisyonu ile belirlenmiştir. Bir birim SOD, 550 nm'de absorbansı izleyerek sitokrom c azaltımının $\% 50$ inhibisyonunu üretmek için gereken enzim miktarı olarak tanımlanmıştır. pH 7.8' deki $50 \mathrm{mM}$ fosfat tamponunun bir mililitre reaksiyon karışımı $0.1 \mathrm{mM}$ EDTA, $50 \mu \mathrm{M}$ hipoksantin, $5.6 \mathrm{mU}$ ksantin oksidaz ve $10 \mu \mathrm{M}$ sitokrom c içermiştir. CAT aktivitesi, dakikada $1.0 \mu \mathrm{mol} \quad \mathrm{H}_{2} \mathrm{O}_{2}$ dismutasyonunu katalize eden enzim miktarının bir CAT enzim birimi olarak tarif edildiği Aebi (1974)'ye göre belirlenmiştir. GST aktivitesinin belirlenmesinde Lemaire vd. (1996) tarafindan önerilen yöntem kullanılmıştır. Bu yöntemde GST aktivitesi, glutatyonun (GSH) 1-kloro-2, 4 dinitrobenzenem'e (KDNB) konjugasyonu nedeni ile $340 \mathrm{~nm}$ 'deki absorbansın değişmesiyle belirlenmiştir. Reaksiyon karışımı $0.2 \mathrm{M}$ fosfat tamponu (pH 7.4), 0.2 mM KDNB, $0.2 \mathrm{mM} \mathrm{GSH}$ içermiştir. Sonuçlar $\mathrm{U} / \mathrm{mg}$ protein olarak verilmiştir.

\subsection{RNA izolasyonu ve $q R T-P C R$}

Total RNA izolasyonu, cDNA sentezi ve qRT-PCR çalışmaları daha önce İcoğlu Aksakal (2019) tarafindan yapilan protokole göre gerçekleştirilmiştir. Total RNA, RNeasy mini kit (Qiagen) kullanılarak üretici firmanın protokolüne göre izole edilmiştir. Kısaca, total RNA izolasyonu için her konsantrasyon grubundan 50 neonat eppendorf tüplerine alınmış, üzerlerine $350 \mu \mathrm{L}$ RLT tamponu ve $\beta$-merkaptoetanol karışımından ilave edilmiş ve her bir tüpe $5 \mathrm{~mm}$ 'lik 1 adet çelik boncuk (Qiagen katalog No: 69989) konulmuştur. Neonatlar homojenizatör (TissueLyser LT, Qiagen) yardımı ile homojenize $(30 \mathrm{~Hz}$ 'de 5 dakika) edilmiştir. Homojenize edilen örneklerin içinden çelik boncuklar çıkarılıp, örnekler 18000 rpm'de $4^{\circ} C^{\prime}$ de 3 dakika santrifüj edilmiştir. Santrifüjlenen numunelerde oluşan 2 fazın üstteki olanından $350 \mu \mathrm{L}$ alınarak steril eppendorf tüplerine aktarılmış ve izolasyon işlemlerine üretici firmanın önerileri doğrultusunda Qiagen-Qiacube DNA-RNA izolasyon robotunda devam edilmiştir. İzole edilen RNA'nın kalitesi ve miktarı Nanodrop ND-spektrofotometresi kullanılarak belirlenmiştir. cDNA sentezi üretici firma tarafindan önerilen protokol doğrultusunda $\mathrm{RT}^{2}$ First Strand cDNA Sentez Kiti (Qiagen) kullanılarak yapılmıştır. Real-time PCR için genlere spesifik primerler 
( $\operatorname{sodF}$ : TGCCGTCGTCTGCTGCTTTGTT; $\operatorname{sodR}$ : TCGGTTGCTGAATACATCGCCGAAT; $\quad c a t \mathrm{~F}$ : CCGTTACAACACTGCCGATGA; catR: AAGCCTGTGCGTTCTTTAGATG; $\quad g s t \mathrm{~F}$ : GGGAGTCTTTTACCACCGTTTC; $\quad g s t \mathrm{R}$ : TCGCCAGCAGCATACTTGTT; $\quad \beta$-aktinF: GCCCTCTTCCAGCCCTCATTCT; $\quad \beta$-aktinR: TGGGGCAAGGGCGGTGATTT), RT $^{2}$ SYBR green master mix (Qiagen) ve cDNA karışımı kullanılmıştır. Real-time PCR reaksiyonları için Rotor-gene Q (Qiagen) Real-time PCR cihazı kullanılmıştır. İç kontrol (housekeeping) geni olarak $\beta$-aktin kullanılmış, her bir genin mRNA ekspresyon seviyesi $\beta$-aktin kullanılarak normalleştirilmiştir. Real Time-PCR işlemleri üç kez tekrarlanmıştır. Real-time PCR sonuçları GenGlobe data analiz veri tabanı kullanılarak analiz edilmiş, sonuçlar kat değişimi olarak verilmiştir (URL-1, 2020).

\subsection{Istatistik analiz}

Real Time-PCR sonuçların istatistiksel değerlendirmesinde Qiagen tarafından desteklenen GeneGlobe data analiz programı tarafindan sağlanan student $t$ testi kullanılmıştır. Gruplar arasındaki farklılıklar $\mathrm{p}<0.05$ önem seviyesinde belirlenmiş̦tir. LC $_{50}$ değeri SPSS 20 paket programında probit analizi kullanılarak hesaplanmıştır. Lipid peroksidasyonu ve antioksidan enzim sonuçlarının analizinde SPSS 20.0 paket programı kullanılarak tek yönlü varyans analizi (ANOVA) yapılmıştır. Gruplar arasındaki farklılıklar $\mathrm{p}<0.05$ önem seviyesinde Duncan'ın çoklu karşılaş̧ırma testi kullanılarak belirlenmiştir. Değerler ortalama \pm standart sapma (mean \pm SD) şeklinde belirtilmiştir.

\section{Bulgular ve tartışma}

Akut toksisite testi boyunca kontrol ve DMSO kontrol gruplarında ölüm meydana gelmemiştir. 48 saatlik $\quad \mathrm{LC}_{50}$ değeri $968.21 \mathrm{nM}$ olarak hesaplanmıştır (Şekil 1). Doz artışına bağlı olarak neonatlarda mortalitenin arttığ $800 \mathrm{nM}$ ziram uygulanan grupta neonatların \%44'ünün öldüğ̈̈ belirlenmiştir. Öte yandan 21 gün boyunca kronik toksisite testine maruz birakılan D. magna neonatlarına uygulanan 154 $\mu \mathrm{g} / \mathrm{L}$ ziramın neonatların \%55'ini öldürdüğü EPA tarafından bildirilmiştir (URL-2, 2009). Hem çalışmamızda kullanılan konsantrasyonların EPA tarafindan bildirilen konsantrasyonlardan farklı olması hem de uygulama sürelerinin farklılık göstermesi nedeni ile deneylerimizdeki ölüm oranı EPA tarafından bildirilen ölüm oranından farklı çıkmıştır.

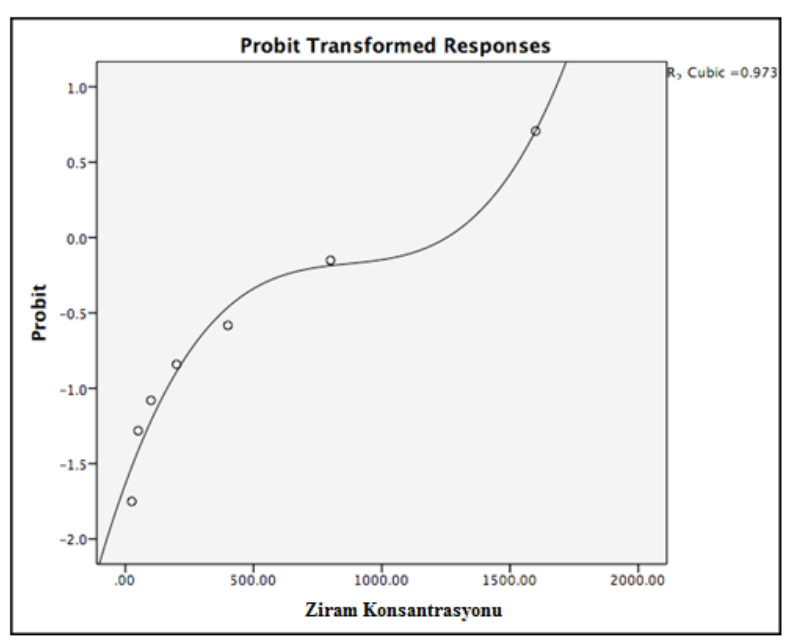

Şekil 1. 48 saatlik LC50 doz yanıt eğrisi (güven aralığ $1 \% 95$ )

Ziram uygulanmış neonatlarda MDA miktarı ve baz1 antioksidan enzim aktivitelerinde meydana gelen değişimler Şekil 2'de verilmiştir. Kontrol grubu ile kıyaslandığında ziram uygulaması MDA miktarını önemli ölçüde artırmıştır. Bu artış bütün uygulama gruplarında istatistiksel olarak önemli bulunmuştur. SOD enzim aktivitesi 200 ve $400 \mathrm{nM}$ ziram uygulama gruplarında kontrole göre istatistiksel olarak anlamlı bir artış göstermiş, 800 nM ziram uygulama grubunda ise kontrole göre anlamlı değişim göstermemiştir. CAT enzim aktivitesi 400 ve $800 \mathrm{nM}$, GST enzim aktivitesi ise 200,400 ve $800 \mathrm{nM}$ ziram uygulama gruplarında kontrole göre istatistiksel olarak önemli oranda $\operatorname{artmıştır~(Şekil~2).~}$

Sod geninin ifadesi ise 200 ve $400 \mathrm{nM}$ ziram uygulama grubunda kontrole göre önemli oranda artış göstermiştir (Şekil 3). Yine cat ve gst genlerinin ifadesi kontrol grubu ile kıyaslandığında ziram uygulaması ile artış göstermiştir (Şekil 3). $\mathrm{Bu}$ artış özellikle yüksek konsantrasyonlarda istatistiksel olarak önemlidir. Antioksidan genlerin ekspresyonunu analiz etmek antioksidan kapasitenin değerlendirilmesine yardımcı olmaktadır (Zhang vd., 2016). Çalışmamızda SOD, CAT ve GST aktivitelerindeki artışlara paralel olarak sod, cat ve gst genlerinin ekspresyonu da artı̧̧ göstermiştir. 

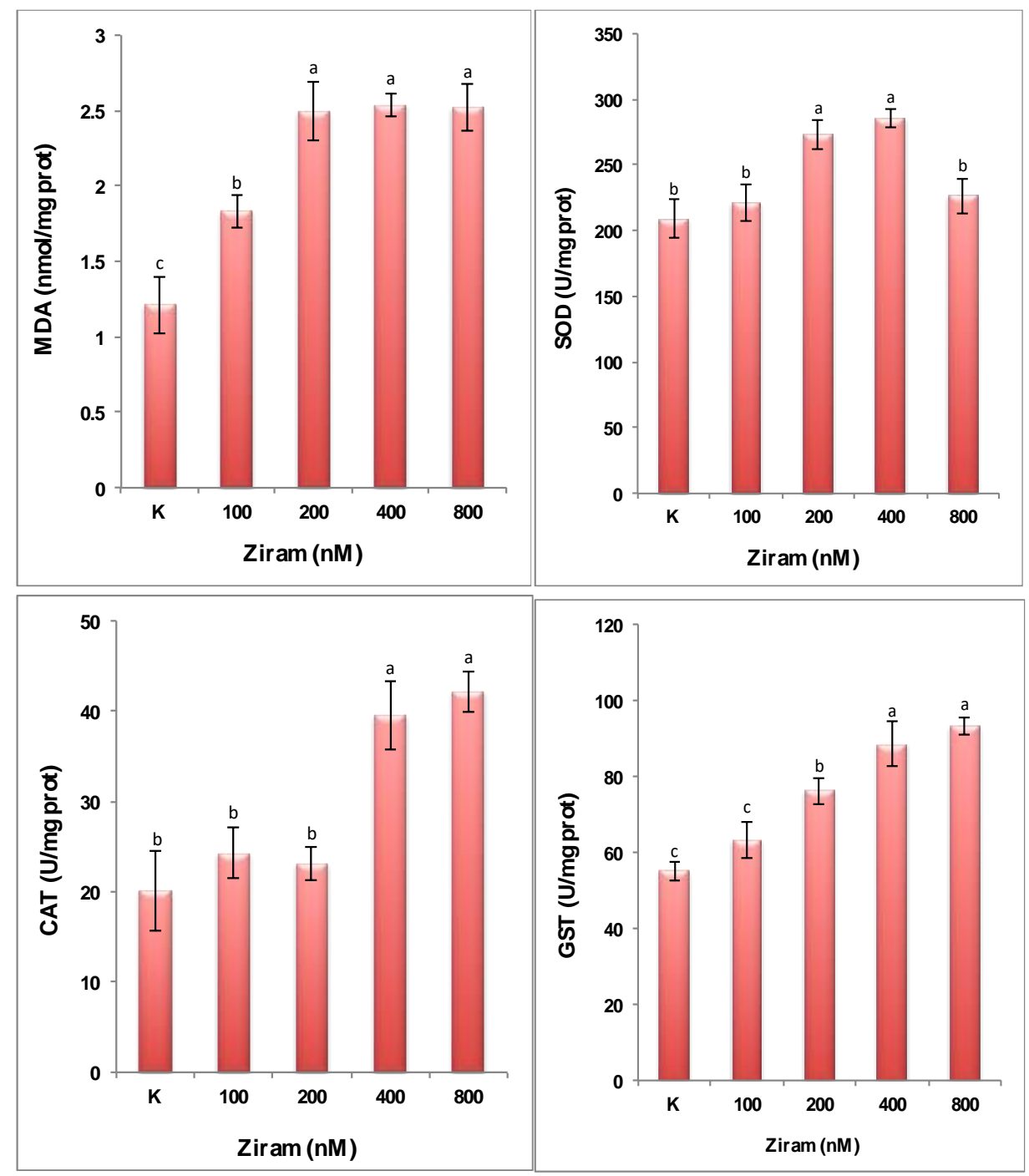

Şekil 2. Ziram uygulmasının D. magna' da MDA miktarı, SOD, CAT ve GST enzim aktivitesi üzerine etkisi (farklı harfler $\mathrm{p}<0.05$ düzeyinde önemli farkl1lıkları ifade etmektedir, veriler ortalama standart sapma olarak ifade edilmiştir)

Bilindiği gibi oksidatif stres biyomarkırları ekotoksikolojide çevresel kirleticilerin toksik etkilerini değerlendirmek için oldukça yoğun kullanılan bir araç haline gelmiştir. Çevresel kirleticilere maruz kalma sucul organizmalarda oksidan/antioksidan oranının dengesini bozarak reaktif oksijen türlerinin artışına ve oksidatif strese neden olabilmektedir. Daha önce yapılan çeşitli çalışmalarda ditiyokarbamat fungusitlerin sucul organizmalarda oksidatif strese neden olduğu bildirilmiştir (Cao vd., 2019; Lulla vd., 2016). Çalışmamızda ziram uygulamasına bağlı olarak MDA miktarının arttığ miktarı genel olarak oksidatif stres altında hücrelerin fonksiyonlarının bozulmasına neden olan lipid peroksidasyonunun belirtecidir. MDA miktarındaki artış zirama maruz kalmanın $D$. magna'da oksidatif stresi indüklediğini işaret etmektedir. SOD ve CAT, organizmaları oksidatif strese karșı korumak için süperoksit anyonunu ve hidrojen peroksidi süpüren antioksidan savunma sisteminin iki önemli bileşenidir. SOD süperoksit radikalinin hidrojen peroksite, CAT ise hidrojen peroksitin su ve oksijene dönüşümünü katalizler. Ortalama stres koşullarında bu enzimlerin aktivitesinin genellikle arttığı, aşırı stres koşullarında ise azaldığı bildirilmiştir. Çalışmamızda zirama maruz kalma CAT aktivitesinde ve cat geninin ifadesinde artışa yol açmıştır. CAT aktivitesi ve cat ekspresyonundaki artış bu enzimin reaktif oksijen türevlerini süpürme özelliğine atfedilebilir. Daha önce yapılan çok sayıda çalışmada pestisitlere maruziyetin $D$. magna'da CAT aktivitesini ve cat geninin ekspresyonunu artırdığı rapor edilmiştir (Cui vd., 2017; Qi vd., 2018). 


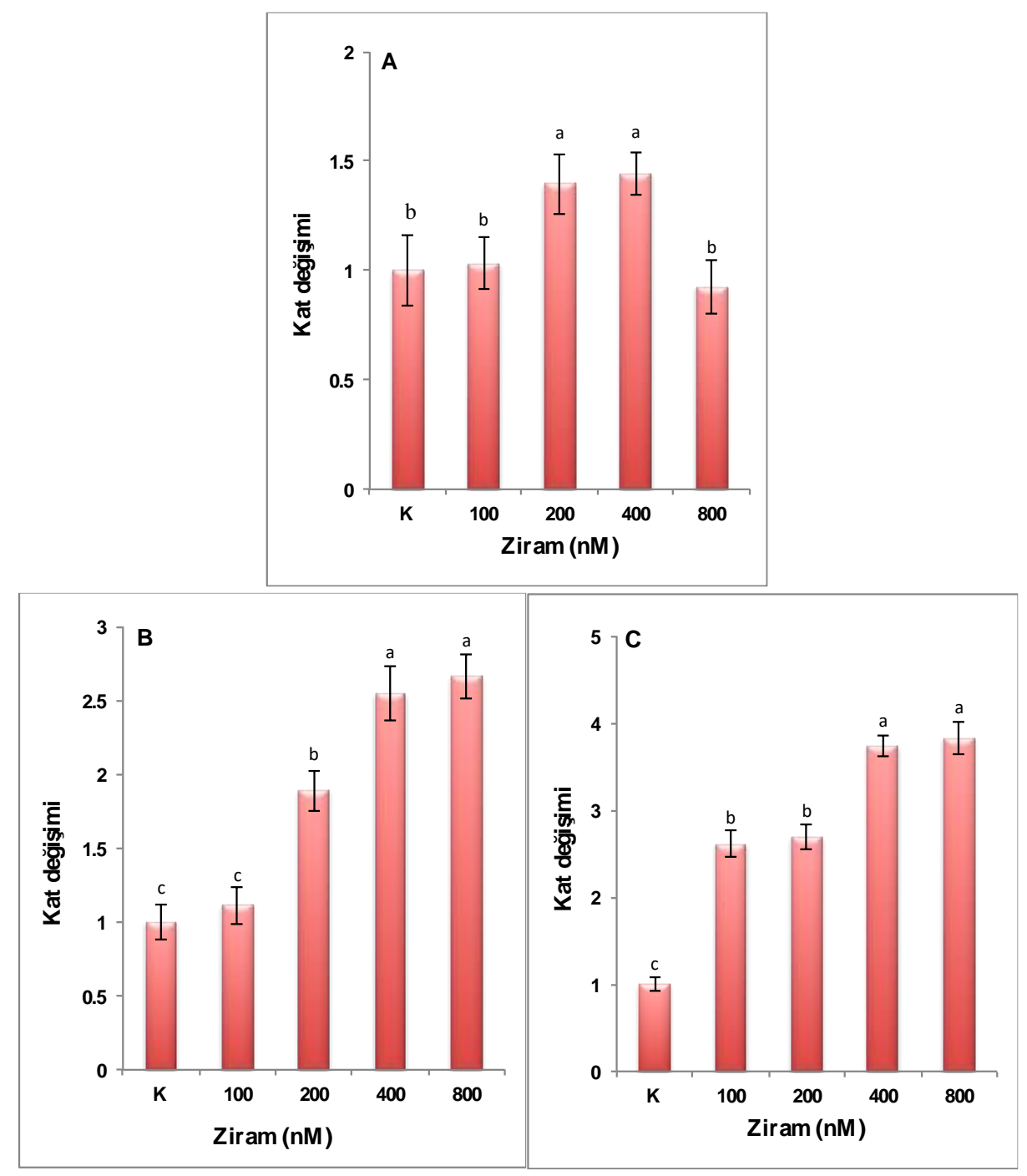

Şekil 3. Ziram uygulmasının D. magna'da, $\operatorname{sod}(\mathrm{A})$, cat (B) ve $g s t(\mathrm{C})$ gen ifadesi üzerine etkisi (farklı harfler $\mathrm{p}<0.05$ düzeyinde önemli farkl11ıkları ifade etmektedir, veriler ortalama standart sapma olarak ifade edilmiştir)

SOD aktivitesi ve sod geninin ekspresyonu 200 ve $400 \mathrm{nM}$ zirama maruz kalan gruplarında artmış, $800 \mathrm{nM}$ grubunda ise değişmemiştir. Sonuçlarımıza benzer olarak trifluraline maruz kalan D. magna'da SOD aktivitesinin nispeten düşük konsantrasyonlarda arttığı daha yüksek konsantrasyonlarda ise kontrole göre değişmediği bildirilmiştir (Song vd., 2017). Bu durum konsantrasyon artışı ile daha fazla fungusitin dokulara girmesine, hücre yapısı ve fonksiyonlarının aşırı stres koşulları altında zarar görmesine ve böylece SOD aktivitesinin düşmesine atfedilmiştir (Calabrese, 2005). Çalışmamızda zirama maruz kalma GST enzim aktivitesini ve $g s t$ gen ifadesini artırmıştır. GST, zenobiyotiklerin GSH'a sentetik konjugasyon reaksiyonlarını katalizleyen ve böylece hücreleri oksidatif strese karş1 koruyan bir biyotransformasyon enzimidir (Zhang vd., 2016). $\mathrm{Bu}$ enzim detoksifikasyon metabolizmasinda önemli rol oynamaktadır. Daha önce yapılan çalışmalarda gst ekspresyonunun, sucul organizmalarda çeşitli toksinlere ve doz-etki ilişkisine yanıt olarak hücrelerin ve organların hassasiyetini belirlemede önemli bir faktör olduğu bildirilmiştir (Song vd., 2017). Çalışmamızda GST aktivitesi ve gst ekspresyonu doz artışına bağlı olarak artış göstermiştir. Sonuçlarımıza paralel olarak İcoğlu Aksakal (2019) ve Song vd. (2017) thifluzamid ve klorpirifosa maruz kalmanın GST aktivitesini ve gst gen ifadesini artırdığını bildirmiştir.

\section{Sonuç}

Sucul organizmalar üzerine pestisitler, ilaçlar, gida koruyucu maddeleri ve kozmetik malzemelerin risk değerlendirmeleri, bu maddelerin çevresel risk değerlendirmelerinin önemli bir parçasıdır. $D$. magna kullanılarak yapılan akut toksisite deneyleri pestisitlerin çevresel risk değerlendirmeleri için oldukça önemli veriler sağlamaktadır. Bu 
çalışmada yapılan akut toksisite deneyleri sonucunda zirama maruz kalmanın D. magna'da antioksidan enzimlerin aktivitesinde ve bu enzimleri kodlayan genlerin ifadesinde önemli değişimlere neden olduğu belirlenmiştir. Bu veriler yapılacak risk değerlendirme çalışmaları için ve gelecekte bu fungusitin makul miktarlarda kullanımı için destek sağlayabilir. Bununla birlikte, ziramin tatlı su omurgasızları ve ekosistem fonksiyonları üzerindeki doğrudan ve dolaylı etkilerini anlamak için daha ayrıntılı biyokimyasal ve moleküler testlerin yapılması gereklidir.

\section{Kaynaklar}

Aebi, H. (1974). Catalase, methods of enzymatic analysis. Elsevier, 673-684. doi: 10.1016/B9780-12-091302-2.50032-3

Bang, S. H., Ahn, J. Y., Hong, N. H., Sekhon, S. S., Kim, Y. H. and Min, J. (2015). Acute and chronic toxicity assessment and the gene expression of Dhb, Vtg, Arnt, CYP4, and CYP314 in Daphnia magna exposed to pharmaceuticals. Molecular and Cellular Toxicology, 11, 153-160. doi: 10.1007/s13273-015-0013-7

Barata, C., Varo, I., Navarro, J. C., Arun, S. and Porte, C. (2005). Antioxidant enzyme activities and lipid peroxidation in freshwater cladoceran Daphnia magna exposed to redox cycling compounds. Comparative Biochemistry and Physiology Part C: Toxicology and Pharmacology, 140, 175-186. doi: 10.1016/j.cca.2005.01.013

Bradford, M. M. (1976). A rapid and sensitive method for the quantitation of microgram quantities of protein utilizing the principle of protein-dye binding. Analytical Biochemistry, 72, 248-254. doi:10.1016/0003-2697(76)90527-3

Calabrese, E. J. (2005). Paradigm lost, paradigm found: The re-emergence of hormesis as a fundamental dose response model in the toxicological sciences. Environmental Pollution, 138, 378411. doi: 10.1016/j.envpol.2004.10.001

Cao, F., Souders II, C. L., Li, P., Adamovsky, O., Pang, S., Qiu, L. and Martyniuk, C. J. (2019). Developmental toxicity of the fungicide ziram in zebrafish (Danio rerio). Chemosphere, 214, 303313. doi: 10.1016/j.chemosphere.2018.09.105

Choi, J. and Oris, J. T. (2000). Evidence of oxidative stress in bluegill sunfish (Lepomis macrochirus) liver microsomes simultaneously exposed to solar ultraviolet radiation and anthracene. Environmental Toxicology and Chemistry: An International Journal, 19, 1795-1799. doi: 10.1002/etc.5620190713
Chou, A. P., Maidment, N., Klintenberg, R., Casida, J. E., Li, S., Fitzmaurice, A. G., Fernagut, P. O., Mortazavi, F., Chesselet, M. F. and Bronstein, J.M. (2008). Ziram causes dopaminergic cell damage by inhibiting E1 ligase of the proteasome. Journal of Biological Chemistry, 283, 34696-34703.

10.1074/jbc.M802210200

Crapo, J. D., McCord, J. M. and Fridovich, I. (1978). Preparation and assay of superioxide dismutases, Methods in enzymology. Elsevier, 382-393. doi: 10.1016/S0076-6879(78)53044-9

Cui, F., Chai, T., Qian, L. and Wang, C. (2017). Effects of three diamides (chlorantraniliprole, cyantraniliprole and flubendiamide) on life history, embryonic development and oxidative stress biomarkers of Daphnia magna. Chemosphere, 169, 107-116. doi: 10.1016/j.chemosphere.2016.11.073

İcoğlu Aksakal, F. (2019). Acute and chronic effects of thifluzamide on Daphnia magna. Turkish Journal of Zoology, 43, 554-559. doi:10.3906/zoo-19098

Kim, H., Kim, J. S. and Lee, Y. M. (2017). Changes in activity and transcription of antioxidant enzymes and heat shock protein 90 in the water flea, Daphnia magna-exposed to mercury. Toxicology and Environmental Health Sciences, 9, 300-308. doi: 10.1007/s13530-017-0335-z

Lemaire, P., Förlin, L. and Livingstone, D. R. (1996). Responses of hepatic biotransformation and antioxidant enzymes to CYP1A-inducers (3methylcholanthrene, $\beta$-naphthoflavone) in sea bass (Dicentrarchus labrax), dab (Limanda limanda) and rainbow trout (Oncorhynchus mykiss). Aquatic Toxicology, 36, 141-160. doi: 10.1016/S0166-445X(96)00819-3

Lulla, A., Barnhill, L., Bitan, G., Ivanova, M. I., Nguyen, B., O’Donnell, K., Stahl, M. C., Yamashiro, C., Klärner, F. G. and Schrader, T. (2016). Neurotoxicity of the parkinson diseaseassociated pesticide ziram is synucleindependent in zebrafish embryos. Environmental Health Perspective, 124, 1766-1775. doi: 10.1289/EHP141

Martin, C. A., Myers, K. M., Chen, A., Martin, N. T., Barajas, A., Schweizer, F. E. and Krantz, D. E. (2016). Ziram, a pesticide associated with increased risk for parkinson's disease, differentially affects the presynaptic function of aminergic and glutamatergic nerve terminals at the Drosophila neuromuscular junction. Experimental Neurology, 275, 232-241. doi: 10.1016/j.expneurol.2015.09.017

Matei, A. M. and Trombetta, L. D. (2016). Exposure of rat hippocampal astrocytes to ziram increases 
oxidative stress. Toxicology and Industrial health, 32, 579-588. doi: $10.1177 / 0748233713504809$

Qi, S., Wang, D. H., Zhu, L., Teng, M., Wang, C., Xue, $\mathrm{X}$. and Wu, L. (2018). Neonicotinoid insecticides imidacloprid, guadipyr, and cycloxaprid induce acute oxidative stress in Daphnia magna. Ecotoxicology and Environmental Safety, 148, 352-358. doi: 10.1016/j.ecoenv.2017.10.042

Shafi, M., Kamil, S. A., Mir, M. S., Darzi, M. M., Bhat, A. S., Shah, S. and Dar, K. H. (2016). Haematological study on the fungicide ziram induced acute, subacute and subchronic toxicity in broiler chickens. Nature Environment and Pollution Technology, 15, 635-639.

Song, Y., Chen, M. and Zhou, J. (2017). Effects of three pesticides on superoxide dismutase and glutathione-S-transferase activities and reproduction of Daphnia magna. Archives of Environmental Protection, 43, 80-86. doi: 10.1515/aep-2017-0010

Thangavel, P., Ramaswamy, M., Sumathiral, K. and Amutha, K. (2005). Individual and combined effects of dimecron-ziram on the levels of serum prolactin and selected minerals of an edible freshwater fish, Oreochromis mossambicus (Peters). Pesticide Biochemistry and Physiology, 81, 24-31. doi: 10.1016/j.pestbp.2004.08.002

URL-1, Qiagen- https://www.qiagen.com/tr/geneglobe. html. 2020

URL-2,

https://www3.epa.gov/pesticides/chem_search/c leared_reviews/csr_PC-034805_1-May09_a.pdf

US-EPA. (2004). Reregistration eligibility decision (RED) facts for ziram. United States Environmental Protection Agency (EPA)-738-F04-008.

US-EPA. (2015). Reregistration eligibility decision (RED) facts for ziram. United States Environmental Protection Agency (EPA) PC Code, 034805.

Zhang, Q.F., Li, Y. W., Liu, Z. H. and Chen, Q. L. (2016). Exposure to mercuric chloride induces developmental damage, oxidative stress and immunotoxicity in zebrafish embryos-larvae. Aquatic Toxicology, 181, 76-85. doi: 10.1016/j.aquatox.2016.10.029 